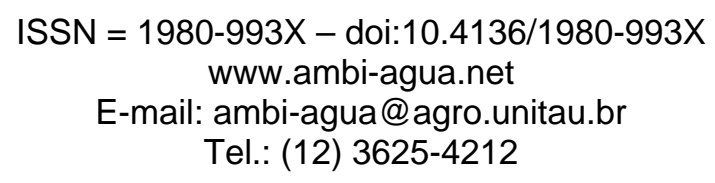

\title{
Nutrient inputs in soil cultivated with coffee crop fertigated with domestic sewage
}

\author{
(http://dx.doi.org/10.4136/ambi-agua.540)
}

\section{Daniel Coelho Ferreira ${ }^{1}$; José Antônio Rodrigues de Souza²; Rafael Oliveira Batista ${ }^{3}$; Claudio Milton Montenegro Campos ${ }^{4}$; Mario Tauzene Afonso Matangue ${ }^{5}$; Debora Astoni Moreira ${ }^{6}$}

\author{
${ }^{1}$ Instituto Federal Fluminense, dcoelho@iff.edu.br; \\ ${ }^{2}$ Instituto Federal Goiano, jarstec@yahoo.com.br; \\ ${ }^{3}$ Universidade Federal Rural do Semi-árido, engbatista@gmail.com; \\ ${ }^{4}$ Universidade Federal de Lavras, cmmcampos@deg.ufla.br; \\ ${ }^{5}$ Universidade de Moçambique, mathauz@yahoo.com.br; \\ ${ }^{6}$ Universidade Estadual de Minas Gerais, deboraastoni@yahoo.com.br
}

\begin{abstract}
Fertigation with wastewaters is a great option for reuse of effluents in agriculture. Domestic effluent can be reused after primary treatment, reducing treatment costs and pollution, also providing water and nutrients to crops. This work aimed to quantify the nutrients income in coffee crop fertigated with domestic sewage. Five treatments were used. $\mathrm{T} 1$ received only clean water, and treatments T2, T3, T4 e T5 received 180, 350, 480 and 638 $\mathrm{mm}$ of sewage, respectively, during four months. Monthly soil analyses allowed to quantify nutrient inputs of $67.45 \mathrm{~kg} \mathrm{ha}^{-1}$ of N, $81.89 \mathrm{~kg} \mathrm{ha}^{-1}$ of P, $33.34 \mathrm{~kg} \mathrm{ha}^{-1}$ of K $\mathrm{K}^{+}, 173.24 \mathrm{~kg} \mathrm{ha}^{-1}$ of $\mathrm{Ca}^{2+}, 49.18 \mathrm{~kg} \mathrm{ha}^{-1}$ of $\mathrm{Mg}^{2+}, 161.56 \mathrm{~kg} \mathrm{ha}^{-1}$ of $\mathrm{Na}^{+}$and $116.19 \mathrm{~kg} \mathrm{ha}^{-1}$ of S. Even though the treatments promoted reductions in fertilization and liming, it was still necessary to complement fertilization of coffee crop fertigated with domestic sewage.
\end{abstract}

Keywords: wastewater; domestic effluent; fertigation; nutrients; coffee crop.

\section{Aporte de nutrientes no solo cultivado com cafeeiro fertirrigado com efluente doméstico}

\section{RESUMO}

O efluente doméstico apresenta potencial de reúso e pode ser utilizado após tratamento primário, reduzindo custos e poluição, fornecendo ainda nutrientes às culturas. Este trabalho teve por objetivo quantificar o aporte de nutrientes no solo cultivado com cafeeiro arábica fertirrigado com efluente doméstico. Foram cinco tratamentos: T1, que recebeu água limpa somente e T2, T3, T4 e T5, os quais receberam lâminas de 180, 350, 480 e 638 mm, respectivamente, durante quatro meses. Análises mensais de solo permitiram quantificar aportes de 67,45 $\mathrm{kg} \mathrm{ha}^{-1}$ de $\mathrm{N}, 81,89 \mathrm{~kg} \mathrm{ha}^{-1}$ de P, 33, $34 \mathrm{~kg} \mathrm{ha}^{-1}$ de $\mathrm{K}^{+}, 173,24 \mathrm{~kg} \mathrm{ha}^{-1}$ de $\mathrm{Ca}^{2+}$, 49,18 $\mathrm{kg} \mathrm{ha}^{-1}$ de $\mathrm{Mg}^{2+}$, 161,56 kg ha ${ }^{-1}$ de $\mathrm{Na}^{+}$e 116, $19 \mathrm{~kg} \mathrm{ha}^{-1}$ de S. A fertirrigação promoveu redução na recomendação de adubação e calagem, requerendo, contudo, complementação de alguns nutrientes, principalmente de $\mathrm{K}^{+}$. A presença de $\mathrm{Na}^{+}$representou riscos de salinização do solo.

Palavras-chave: efluentes domésticos; fertirrigação; nutrientes; fertilização; cafeeiro. 
FERREIRA, D. C.; SOUZA, J. A. R. de; BATISTA, R. O.; CAMPOS, C. M. M.; MATANGUE, M. T. A.; MOREIRA, D. A. Nutrient inputs in soil cultivated with coffee crop fertigated with domestic sewage. AmbiAgua, Taubaté, v. 6, n. 3, p. 77-85, 2011. (http://dx.doi.org/10.4136/ambi-agua.540)

\section{INTRODUCTION}

Fertigation presents innumerable advantages in comparison with conventional methods of fertilization. Reduction of physical injuries in plants, none soil compaction, less energy requirements and better control in nutrient dosages that can be applied according to changeable needs of plants during its cycle. (Silva et al., 2005). Though, it is sometimes necessary to use more soluble fertilizers, which in turn, can increase production costs, also, presenting corrosion problems for the system (CFSEMG, 1999).

On the other hand, the use of wastewater in fertigation has the great advantage of being a readily available source of quality water, promoting reuse, nutrients recycling, reduction in chemical fertilizers usage and contributions for environment preservation (Van der Hoek et al., 2002; USEPA, 2006).

There are many types of wastewaters, but domestic sewage is on the spotlight mainly due to the amount produced, which makes it a great environment issue for disposal in water resources, not allowing this action to be performed without treatment. Yet, the area required for treating wastewater usually is very large, along with the high operational costs. Thereupon, soil disposal has been seen as a viable technology for treating and reusing domestic sewage, using its fertilization potential in accordance with economical, environmental and public health issues (Hespanhol, 2002; Jamwal and Mittal, 2010).

According to Van der Hoek et al. (2002) the use of urban wastewater as a source of nutrients is one of the advantages regarded to its use in agriculture and many other authors have present the benefits of domestic sewage application in agriculture as source of nutrients and water. They have reported reduction in exchangeable $\mathrm{Al}^{3+}$ contents and aluminum saturation, increases in contents of $\mathrm{N}, \mathrm{P}, \mathrm{K}^{+}, \mathrm{S}, \mathrm{Ca}^{2+}, \mathrm{Mg}^{2+}$, sum of bases (SB), organic matter, cation exchange capacity (CEC), base saturation (V) and micronutrients (Al-Nakshabandi et al., 1997; Falkiner and Smith, 1997; Léon and Cavalinni, 1999; Fonseca, 2001; Jnad et al., 2001; Hespanhol, 2002; Medeiros et al., 2005; Souza et al., 2005; Toze, 2006; Heidapour et al., 2007; Morari and Giardini, 2009, Ferreira et al., 2010), despite benefic alterations in soil hydraulic conductivity, infiltration rate and apparent density, mainly due to the great amount of organic matter added (Matos, 2003), which acts like a soil conditioner, enhancing its water retention capacity (WHO, 2004).

Fonseca (2001) and Souza et al. (2005) reported substantial reductions in conventional fertilizers, eliminating indeed nitrogen fertilization. Hespanhol (2002) affirms that, depending on the irrigation depth applied, till 60 and $300 \mathrm{~kg} \mathrm{ha}^{-1} \mathrm{ano}^{-1}$, of $\mathrm{P}$ and $\mathrm{N}$ can be provided, respectively. The USEPA (2006) have also presented results of better yields for annual crops due to wastewater application. Léon and Cavallini (1999) avowed that wastewaters are effective in nutrient transport required for crops and also reported increases in bean and fruit yields, principally due to nitrogen provision. Al Nakshabandi et al. (1997) observed increases in egg plant yields, probably regarded to effluent nutrients. Hespanhol (2002) reported better yields in beans, potato, cotton, wheat and rice.

Hence, this work aimed to evaluate the potential use of domestic sewage as a source of nutrients through fertigation of coffee crop and moreover, quantify the addition of some essential nutrients onto the soil.

\section{MATERIAL AND METHODS}

The experiment was conducted at the Experimental Area of Waste Treatments (AETR), located at the Federal University of Viçosa (UFV), on the Agricultural Engineer Department (DEA). The soil, according to Souza et al. (2010), is a haplic cambissol (inceptsol) with latosol B textural. This experiment used only part of the AETR, i.e., 0,14 ha of coffee crop 
FERREIRA, D. C.; SOUZA, J. A. R. de; BATISTA, R. O.; CAMPOS, C. M. M.; MATANGUE, M. T. A.; MOREIRA, D. A. Nutrient inputs in soil cultivated with coffee crop fertigated with domestic sewage. AmbiAgua, Taubaté, v. 6, n. 3, p. 77-85, 2011. (http://dx.doi.org/10.4136/ambi-agua.540)

and the structure used to pre treat and apply the wastewater. The pre treatment was composed by a screen, followed by a settling basin and a box (Sand retention device), for oil and grass removal. Hence, the wastewater was conducted to a sand filter. After filtering, it was stored in tank of 2,500 L, from where it was pumped into the drip irrigation system. Before entering the system the wastewater passed through a 120 mesh disc filter, able to filter till $5.0 \mathrm{~m}^{3} \mathrm{~h}^{-1}$.

The soil was chemically characterized initially by complete routine analysis. After each month, a soil sample was collected for each treatment at three soil depths namely, $0-20 \mathrm{~cm}$, $20-40 \mathrm{~cm}$ and $40-60 \mathrm{~cm}$. One simple sample was taken at each repetition, then, joined to form a composed sample for that treatment.

The wastewater application was done during four months and the total fertigation depths applied to each treatment were calculated based on the mean $\mathrm{Na}^{+}$concentrations reported by Medeiros et al. (2005) and Souza et al. (2005), which have used the same source of sewage. During the experiment the nutrients contents were analyzed monthly in the domestic effluent.

The experiment was carried out in split split plots, using the randomized block design with four repetitions (Figure 1). The plots were composed by the treatments (different fertigation depths), the sub plots were the three soil depths sampled, and sub sub plot was the times evaluated (each of the four months). Each experimental plot was formed by eight coffee trees, occupying an area of $15 \mathrm{~m}^{2}$. Only the area of four coffee trees, in the middle of the each plot was used as sampling area. The other plants were left as separation between treatments.

\begin{tabular}{|c|c|c|c|c|c|c|}
\hline & B1 & T3 & $\mathrm{T} 2$ & $\mathrm{~T} 1$ & T5 & $\mathrm{T} 4$ \\
\hline \multirow{2}{*}{$\begin{array}{l}\text { Sewage } \\
\text { Storage }\end{array}$} & B3 & T5 & T4 & T3 & T2 & T1 \\
\hline & \multirow[b]{2}{*}{ B2 } & & & & & \\
\hline & & T5 & $\mathrm{T} 1$ & T4 & T3 & T2 \\
\hline \multirow{2}{*}{$\begin{array}{l}\text { Water } \\
\text { Storage }\end{array}$} & \multirow[b]{2}{*}{ B4 } & & & & & \\
\hline & & T4 & T2 & T5 & T3 & T1 \\
\hline
\end{tabular}

Figure 1. Treatment distribution in the field.

The fertigation depths were 180, 350, 480 and $638 \mathrm{~mm}$, for the treatments T2, T3, T4 e T5, respectively. T1 received the same depth of T5, but, only clean water. The daily depths applied were 4.85, 6.80, 6.47, and $10.62 \mathrm{~mm}$, on April, May, June and July, respectively. After the application of the fertigation depths, the addition of nutrients to the soil was assessed.

The effluent application was suspended immediately after the fertigation depth established for each treatment was reached. Afterwards, the supplemental fertilization was done with potassium chloride $(\mathrm{KCl})$, discounting the amounted provided by the wastewater. The assessment of nutrient doses applied was done by multiplying the nutrient concentration in the wastewater (mg L ${ }^{-1}$ ) and the fertigation depth (mm) during the month. After reaching the fertigation depth previously stated, the treatment received only clean water.

Daily fertigation and irrigation were preferable because of the short time available for carrying out the experiment. Therefore, no weather or soil data were used to fertigation management. 
FERREIRA, D. C.; SOUZA, J. A. R. de; BATISTA, R. O.; CAMPOS, C. M. M.; MATANGUE, M. T. A.; MOREIRA, D. A. Nutrient inputs in soil cultivated with coffee crop fertigated with domestic sewage. AmbiAgua, Taubaté, v. 6, n. 3, p. 77-85, 2011. (http://dx.doi.org/10.4136/ambi-agua.540)

\section{RESULTS AND DISCUSSION}

The domestic effluent presented different concentrations of elements during the experiment, thus confirming the season influence on its characteristics. Those variations were also confirmed by Medeiros et al. (2005), Batista (2007), and Souza et al. (2010), which have used the same source of wastewater in their tests. On Table 1 are shown the mean concentrations for some nutrients in the wastewater.

Table 1. Chemical characterization of the domestic wastewater.

\begin{tabular}{c|rrrrrrrr}
\hline \multirow{2}{*}{ Month } & \multicolumn{7}{|c}{ Nutrient concentration in the wastewater $\left(\mathbf{m g} \mathbf{~ L}^{-\mathbf{1}}\right)$} \\
\cline { 2 - 9 } & \multicolumn{1}{|c}{$\mathbf{N}$} & $\mathbf{P}$ & $\mathbf{K}^{+}$ & $\mathbf{C a}^{2+}$ & $\mathbf{M g}^{\mathbf{2}}$ & $\mathbf{N a}^{+}$ & $\mathbf{M n}$ & $\mathbf{S}$ \\
\hline April & - & 6,39 & 5,40 & 16,53 & 4,28 & 29,13 & - & 77,12 \\
May & 6,16 & 7,64 & 8,00 & 52,8 & 15,23 & 41,00 & 0,03 & 22,64 \\
June & 30,80 & 10,14 & 3,88 & 19,15 & 5,35 & 43,00 & 0,06 & - \\
July & 6,16 & 21,07 & 4,32 & 21,15 & 6,09 & 34,00 & 0,02 & - \\
\hline Mean & 14,37 & 11,31 & 5,40 & 27,41 & 7,74 & 36,78 & 0,04 & 49,88 \\
\hline
\end{tabular}

“_” No sampling was done for this element.

The $\mathrm{N}$ contents ranged widely being always below the typical concentration suggested by some authors, which is, 40 to $80 \mathrm{mg} \mathrm{L}^{-1}$ (Von Sperling, 2005) and $50 \mathrm{mg} \mathrm{L}^{-1}$ (Pescod, 1992). The recommendation of $\mathrm{N}$ is based on its leaf contents or on the organic matter in the soil, but, when none of these values are known it is suggested to apply $350 \mathrm{~kg} \mathrm{ha}^{-1}$ in order to achieve yields of $30-40$ sacks (CFSEMG, 1999). The amount provided by the wastewater was $67 \mathrm{~kg} \mathrm{ha}^{-1}$ (Table 2) and therefore, the recommended dose decreased to $282 \mathrm{~kg} \mathrm{ha}^{-1}$, representing a reduction of $19 \%$ in $\mathrm{N}$ fertilization.

The $\mathrm{P}$ concentration varied as well. It was smaller in the experiment beginning always close to the lower limit suggested by Von Sperling (2005), which is, $4 \mathrm{mg} \mathrm{L}^{-1}$. On the last month there was a great alteration and the $\mathrm{P}$ concentration has reached $21.1 \mathrm{mg} \mathrm{L}^{-1}$, really far from the typical range for domestic wastewater. Phosphorus is found in many different forms in domestic wastewater (organic, complex inorganic, soluble orthophosphate) and can be in available or unavailable forms. This change in concentration can be related to variations among these forms in the wastewater.

Regarding $\mathrm{P}$ fertilization, it is important to emphasize its high adsorption and immobilization in high weathered tropical soils, especially in clay soils with elevated contents of $\mathrm{Fe}$ and $\mathrm{Al}$ oxides that retain $\mathrm{P}$ strongly and release it in very slow rates. It could be observed in this experiment, by checking the values of remaining P (Prem), which usually is found low, as seen in this work. The $\mathrm{P}$ apportion was adequate, but, soil adsorption could diminish its availability for plants. However, the wastewater application was sufficient to modify the soil classification regarding the $\mathrm{P}$ content, which, in the beginning of the tests was very low $\left(1.6 \mathrm{mg} \mathrm{dm}^{-3}\right.$ ) and after wastewater application it rose for 10.42 , being therefore classified as medium. 
FERREIRA, D. C.; SOUZA, J. A. R. de; BATISTA, R. O.; CAMPOS, C. M. M.; MATANGUE, M. T. A.; MOREIRA, D. A. Nutrient inputs in soil cultivated with coffee crop fertigated with domestic sewage. AmbiAgua, Taubaté, v. 6, n. 3, p. 77-85, 2011. (http://dx.doi.org/10.4136/ambi-agua.540)

Table 2. Nutrients provided to soil due to wastewater fertigation of $638 \mathrm{~mm}$ depth.

\begin{tabular}{c|crrrrrc}
\hline \multirow{2}{*}{ Month } & \multicolumn{7}{|c}{ Nutrientes doses $\left(\mathbf{k g ~ h a}^{-\mathbf{1}} \mathbf{)}\right.$} \\
& $\mathbf{N}$ & $\mathbf{P}$ & \multicolumn{1}{c}{$\mathbf{K}^{+}$} & $\mathbf{C a}^{\mathbf{2}}$ & $\mathbf{M g}^{\mathbf{2}}$ & $\mathbf{N a}^{+}$ & $\mathbf{S}$ \\
\hline April & - & 6,82 & 5,77 & 17,64 & 4,57 & 31,10 & 82,34 \\
May & 9,21 & 11,42 & 11,96 & 78,93 & 22,77 & 61,30 & 33,84 \\
June & 43,85 & 14,43 & 5,52 & 27,26 & 7,62 & 61,22 & - \\
July & 14,39 & 49,21 & 10,09 & 49,39 & 14,22 & 7,94 & - \\
\hline Total & 67,45 & 81,89 & 33,34 & 173,24 & 49,18 & 161,56 & 116,19 \\
\hline
\end{tabular}

“_” No sampling was done for this element.

The concentration of $\mathrm{K}^{+}$was always below the mean values reported by Medeiros et al. (2005) and Souza et al. (2005), which obtained mean concentrations of $39.1 \mathrm{mg} \mathrm{L}^{-1}$ e $32.3 \mathrm{mg}$ $\mathrm{L}^{-1}$, respectively. Pescod (1992) and WHO (2004) affirm that the $\mathrm{K}^{+}$concentrations are around $30 \mathrm{mg} \mathrm{L}^{-1}$ in domestic wastewater. In the first soil sampling the $\mathrm{K}^{+}$contents were considered very low and, at the final sampling, even after application of $638 \mathrm{~mm}$ depth of wastewater (T5), the potassium content stayed practically the same (Table 3). Despite being not enough to fulfill the crop requirements, the amount provided to the soil by domestic wastewater application was $33.3 \mathrm{~kg} \mathrm{ha}^{-1}$ (Table 2).

According to the CFSEMG (1999), the recommended dose of potassium for a yield of 30 sacks ha ${ }^{-1}$ is $300 \mathrm{~kg} \mathrm{ha}^{-1}$ of $\mathrm{K}_{2} \mathrm{O}$ (Table 3 ). Hence, the dose to be applied for complementing the $\mathrm{K}^{+}$fertilization was reduced to $259.9 \mathrm{~kg} \mathrm{ha}^{-1}$ of $\mathrm{K}_{2} \mathrm{O}$, which represents a $13 \%$ reduction.

The results achieved here confirm the reports of Medeiros et al. (2005) and Souza et al. (2010). Those authors did not found amounts of $\mathrm{K}^{+}$applied able to satisfy the coffee crop needs. Matos (2003) validate that the $\mathrm{K}^{+}$concentration in domestic wastewater is low, principally when compared with $\mathrm{Ca}^{2+}$ and $\mathrm{Mg}^{2+}$ concentrations. Thus, in order to provide adequate amounts of potassium in areas fertigated with domestic wastewater, it is mandatory to complement fertilization with a chemical source of $\mathrm{K}^{+}$.

Table 3. $\mathrm{P}$ and $\mathrm{K}$ contents in soil at the initial and final sampling and recommendation of doses for each treatment.

\begin{tabular}{|c|c|c|c|c|c|c|c|}
\hline & \multicolumn{5}{|c|}{ Final Sampling } & \multicolumn{2}{|c|}{ Recommendation } \\
\hline & $\mathbf{P}$ & Class & $\mathbf{K}$ & Class & Prem & $\mathbf{P}_{2} \mathbf{O}_{5}$ & $\mathrm{~K}_{2} \mathrm{O}$ \\
\hline & \multicolumn{2}{|c|}{$\mathrm{mg} \mathrm{dm}^{-3}$} & \multicolumn{2}{|c|}{$\mathrm{mg} \mathrm{dm}^{-3}$} & $\mathrm{mg} \mathrm{dm}^{-3}$ & \multicolumn{2}{|c|}{ kg ha $^{-1}$} \\
\hline T1 & 8,27 & Low & 53,5 & Low & 24,5 & 50 & 300 \\
\hline $\mathbf{T} 2$ & 9,36 & Medium & 43,9 & Low & 25,39 & 40 & 300 \\
\hline T3 & 8,82 & Medium & 32,35 & Low & 25,79 & 40 & 300 \\
\hline T4 & 3,95 & Very Low & 29,5 & Low & 25,81 & 50 & 300 \\
\hline \multirow[t]{4}{*}{ T5 } & 10,24 & Medium & 27,95 & Low & 25,94 & 40 & 300 \\
\hline & \multicolumn{5}{|c|}{ Initial Sampling } & \multicolumn{2}{|c|}{ Recommendation } \\
\hline & $\mathbf{P}$ & Class & $\mathbf{K}$ & Class & Prem & $\mathbf{P}$ & $\mathbf{K}$ \\
\hline & 1,6 & Very Low & 27 & Low & 25,7 & 50 & 300 \\
\hline
\end{tabular}

Note: Prem = remaining $\mathrm{P}$. 
FERREIRA, D. C.; SOUZA, J. A. R. de; BATISTA, R. O.; CAMPOS, C. M. M.; MATANGUE, M. T. A.; MOREIRA, D. A. Nutrient inputs in soil cultivated with coffee crop fertigated with domestic sewage. AmbiAgua, Taubaté, v. 6, n. 3, p. 77-85, 2011. (http://dx.doi.org/10.4136/ambi-agua.540)

In Table 4 are presented values of some elements used for assessing the amount of lime to be applied according the $\mathrm{Al}^{3+}$ neutralization method. It is shown that there was a reduction in $\mathrm{Al}^{3+}$ contents and also increments in $\mathrm{Ca}^{2+}$ and $\mathrm{Mg}^{2+}$, which worked together for increasing both bases saturation index and potential cation exchange capacity (CEC).

The wastewater application promoted reductions ranging from 15 to $26 \%$ in lime recommendation, presenting a considerable economy in use of lime, since the minimal application for this soil corrective stays, in general, around 2,5 $\mathrm{t} \mathrm{ha}^{-1}$ (CFSEMG, 1999). When using limes with higher $\mathrm{Mg}$ concentrations, economy can be even higher, since these corrective are more expensive. Thereupon, depending on the amounts of $\mathrm{Mg}$ provided by wastewater application, correction could be carried out only with regular lime, usually cheaper.

The treatments $\mathrm{T} 1$ and $\mathrm{T} 2$ received complementary fertilization with $\mathrm{K}^{+}$, which have also contributed for increases in $\mathrm{Va}, \mathrm{T}, \mathrm{t}$ and also, $\mathrm{K}^{+}$contents, which were 53,5 and 43,9 $\mathrm{cmol}_{\mathrm{c}} \mathrm{dm}^{3}$, as seen in Tables 3 and 4 .

Table 4. Some nutrient contents and lime recommendation by the $\mathrm{Al}^{3+}$ neutralization method.

\begin{tabular}{|c|c|c|c|c|c|c|c|c|}
\hline & $\mathrm{Al}^{3+}$ & $\mathrm{Ca}^{2+}$ & $\mathrm{Mg}^{2+}$ & $\mathbf{t}$ & $\mathbf{T}$ & Va & \multicolumn{2}{|c|}{ Liming Reduction } \\
\hline & \multicolumn{5}{|c|}{$\mathrm{cmol}_{\mathrm{c}} \mathrm{dm}^{-3}$} & $\%$ & tha h $^{-1}$ & $\%$ \\
\hline Beginning & 0,87 & 0,41 & 0,15 & 1,52 & 3,55 & 18,3 & 4,50 & 0 \\
\hline Final T1 & 0,78 & 0,83 & 0,23 & 1,99 & 5,42 & 21,37 & 3,83 & 15 \\
\hline Final T2 & 0,58 & 0,85 & 0,23 & 1,82 & 4,73 & 26,16 & 3,46 & 23 \\
\hline Final T3 & 0,54 & 0,87 & 0,26 & 1,81 & 4,98 & 24,99 & 3,33 & 26 \\
\hline Final T4 & 0,64 & 0,83 & 0,20 & 1,80 & 4,80 & 24,42 & 3,61 & 20 \\
\hline Final T5 & 0,74 & 0,80 & 0,21 & 1,89 & 4,44 & 26,00 & 3,81 & 15 \\
\hline
\end{tabular}

Note: $\mathrm{t}=$ effective CEC; $\mathrm{T}=\mathrm{CEC}$ at $\mathrm{pH} 7,0 ; \mathrm{Va}=$ base saturation.

The $\mathrm{Na}^{+}$contents behave seasonally, as related by Medeiros et al. (2005) and Souza (2010), which have used the same source of sewage in their studies. The values were quite high, providing a total of $161,51 \mathrm{~kg} \mathrm{ha}^{-1}$ during the experimental period. Souza et al. (2010) reported apportions of 286,38 $\mathrm{kg} \mathrm{ha}^{-1}$ of $\mathrm{Na}^{+}$after application of $743 \mathrm{~mm}$ of domestic effluent, which probably promoted reduction in hydraulic conductivity of the soil tested. The presence of $\mathrm{Na}^{+}$in domestic sewage is the main concern regarding its reuse in agricultural crops, since it represents risks of salinization and reduction of crop yields (Matos, 2003). Ferreira et al. (2010) observed increments of $\mathrm{Na}^{+}$contents in all the soil samples that were fertigated with domestic sewage. Also, increases in sodium adsorption rate (SAR) and Percentage of exchangeable sodium (PES) were reported, representing therefore moderate risks of soil salinization. As the fertigation depths were increased it promoted $\mathrm{Na}^{+}$leaching along the soil profile.

The amount of S was enough according the coffee crop needs. In general, this nutrient does not represent limitations for crops, once many fertilizers have some amount of $\mathrm{S}$, such limes, ammonium sulfate and superphosphates. So, the use of them provide also the $\mathrm{S}$ requirements.

\section{CONCLUSIONS}

The fertigation of domestic wastewater in crops was suitable for reuse of this effluent in agriculture, reducing its pollution hazard. The application of domestic wastewater in soil cultivated with coffee was efficient in supplying some essential nutrients for plant growth, 
such $\mathrm{N}, \mathrm{P}, \mathrm{K}^{+}, \mathrm{Ca}^{2+}, \mathrm{Mg}^{2+}$ and $\mathrm{S}$, promoting augments in concentration of these nutrients in soil, sum of bases, decreases in $\mathrm{Al}^{3+}$ contents and also reductions in recommended doses of fertilizers and liming, therefore, decreasing costs with fertilization. The $\mathrm{Na}^{+}$concentrations represented great concern since it can head to soil salinization. However, due to imbalance of some nutrients within the domestic wastewater as well the seasonality of concentrations, regular monitoring in a monthly basin should be done, in order to assess the amounts applied to the soil and hence, complement more precisely the nutrients for the crops and also avoiding soil salinization.

\section{ACKNOWLEDGMENTS}

We thank the Federal University of Viçosa by the experimental area use and the CNPq for funding support. Also, we thank professors Antonio Matos, Antonio Alves Soares, Mauro Martinez, Roberto Novaes and Julio Neves for helping in data analysis.

\section{REFERENCES}

AL-NAKSHABANDI, G. A.; SAQQAR, M. M.; SHATANAWI, M. R.; FAYYAD, M.; ALHORANI, H. Some environmental problems associated with the use of treated wastewater for irrigation in Jordan. Agricultural Water Management, Amsterdam, v. 34, p. 81- 94, 1997. http://dx.doi.org/10.1016/S0378-3774(96)01287-5

ALVAREZ, V. H.; RIBEIRO, A. C. Recomendações para uso de corretivos e fertilizantes em Minas Gerais, $5^{a}$ Aproximação. Viçosa, MG: Comissão de Fertilidade do Solo do Estado de Minas Gerais - CFSEMG, 1999.

BATISTA, R. O. Desempenho de sistema de irrigação por gotejamento utilizado na aplicação de água residuária de suinocultura. 2007. Tese (Doutorado em Engenharia Agrícola) - Universidade Federal de Viçosa, Viçosa, MG, 2007.

COMISSÃO DE FERTILIDADE DO SOLO DO ESTADO DE MINAS GERAIS. Recomendações para o uso de corretivos e fertilizantes em Minas Gerais. 5. ed. Lavras, 1999. 359 p.

FALKINER, R. A.; SMITH, C. J. Changes in soil chemistry in effluent- irrigated Pinus radiata and Eucalyptus grandis. Australian Journal of Soil Research, Victoria, v. 35, p. 131-147, 1997. http://dx.doi.org/10.1071/S95080

FERREIRA, D. C.; SOUZA, J. A. R.; BATISTA, R. O.; MATANGUE M. T. A.; CAMPOS, C. M. M. Nutrient inputs in soil cultivated with coffee crop fertigated with domestic sewage. In: CONVENCIÓN INTERNACIONAL SOBRE MEDIO AMBIENTE Y DESARROLlO SOSTENIBLE, 8., 4-8 jul. 2010, Havana. Proceedings... Havana: Agencia de Medio Ambiente, 2010.

FONSECA, A. F. Disponibilidade de nitrogênio, alterações nas características químicas do solo e do milho pela aplicação de efluente de esgoto tratado. 2001. 110f. Dissertação (Mestrado em Engenharia Agrícola) - Escola Superior de Agricultura Luiz de Queiroz (ESALQ), Piracicaba, 2001.

HEIDARPOUR, M.; MOSTAFAZADEH-FARD, B.; KOUPAIAND, J. A.; MALEKIAN, R. The effects of treated wastewater on soil chemical properties using subsurface and surface irrigation methods. Agricultural Water Management, Amsterdam, n. 90, p. 87-94, 2007. 
HESPANHOL, I. Potencial de reuso de água no Brasil: agricultura, indústria, municípios, recarga de aqüíferos. Revista Brasileira de Recursos Hídricos, Rio de Janeiro, v. 7 n.4, p. 75-95, out./dez. 2002.

JAMWAL, P. MITTAL, A. K. Reuse of treated sewage in Delhi city: microbial evaluation of STPs ad reuse options. Resources, Conservation and Recycling. v. 54, n. 4, p. 211221, Feb. 2010

JNAD, I.; LESIKAR, B.; KENIMER, A.; SABBAGH, G. Subsurface drip dispersal of residential effluent: II. Soil hydraulic characteristics. Transactions of the ASAE, St. Joseph, v. 44, n. 5, 2001.

LÉON S. G.; CAVALLINI, J. M. Tratamento e uso de águas residuárias industriais. Campina Grande: Universidade Federal da Paraíba, 1999. 110 p.

MATOS, A. T. Aproveitamento de efluentes líquidos domésticos e agroindustriais na agricultura. In: ENCONTRO DE PRESERVAÇÃO DE MANANCIAIS DA ZONA DA MATA MINEIRA, 3., 2003, Viçosa, MG. Anais... Viçosa, MG: UFV, 2003. 392p

MEDEIROS, S. S., SOARES, A. A., FERREIRA, P. A., NEVES, J. C. L., MATOS, A. T.; SOUZA, J. A. A. Utilização de água residuária de origem doméstica na agricultura: estudo das alterações químicas do solo. Revista Brasileira de Engenharia Agrícola e Ambiental, Campina Grande, v. 9, n. 4, p. 603-612, 2005.

MORARI, F.; GIARDINI, L. Municipal wastewater treatment with vertical flow constructed wetlands for irrigation reuse. Ecological Engineering, v. 35, n. 5, p. 643-653, May 2009.

PESCOD, M. B. Wastewater treatment and use in agriculture. Rome: FAO, 1992. 125p. (Irrigation and Drainage Paper, 47).

SILVA, A. M.; COELHO, G. \& SILVA, R. A. Épocas de irrigação e parcelamento de adubação sobre a produtividade do cafeeiro, em quatro safras. Revista Brasileira de Engenharia Agrícola e Ambiental, Campina Grande, v. 9, n. 3, p. 314-319, 2005.

SOUZA, J. A. A.; RAMOS, M. M.; SOARES, A. A.; NEVES, J. C. L.; MEDEIROS, S. S.; SOUZA, J. A. Efeitos da fertirrigação com água residuária de origem urbana sobre a produtividade do cafeeiro. Revista Brasileira de Engenharia Agrícola e Ambiental, Campina Grande, v. 9, p. 128-132, 2005.

SOUZA, J. A. A.; BATISTA, R. O.; RAMOS, M. M..; SOARES, A. A. Alteração nas características físicas do solo decorrentes da aplicação de esgoto doméstico tratado. Acta Scientiarum. Technology, v. 33, p. 5-8, 2010. Disponível em: <http:dx.doi.org/10.4025/actascitechnol.v32i4.5349>. Acesso: 16 set. 2011.

TOZE, S. Reuse of effluent water - benefits and risks. Agricultural Water Management, Amsterdam, v. 80, p. 147-159, Feb. 2006.

UNITED STATES ENVIRONMENTAL PROTECTION AGENCY - U.S.EPA. Land treatment of municipal wastewater effluents. Washington, 2006.

VAN DER HOEK, W.; HASSAN, U. M.; ENSINK, J. H. J.; FEENSTRA, S.; RASCHIDSALLY, L.; MUNIR, S. et al. Urban wastewater: a valuable resource for agriculture. A case study from Horoonabad, Pakistan. Colombo: International Water Management Institute, 2002. (Research Report, 63). 
FERREIRA, D. C.; SOUZA, J. A. R. de; BATISTA, R. O.; CAMPOS, C. M. M.; MATANGUE, M. T. A.; MOREIRA, D. A. Nutrient inputs in soil cultivated with coffee crop fertigated with domestic sewage. AmbiAgua, Taubaté, v. 6, n. 3, p. 77-85, 2011. (http://dx.doi.org/10.4136/ambi-agua.540)

VON SPERLING, M. Introdução à qualidade das águas e ao tratamento de esgotos. 3. ed. Belo Horizonte: Departamento de Engenharia Sanitária e Ambiental; Universidade Federal de Minas Gerais, 2005. v.1. 452 p.

WORLD HEALTH ORGANIZATION - WHO. Health guidelines for the use of wastewater in agriculture and aquaculture. Geneva, 2004. (Technical Report, 74). 